\title{
Nigerian Pentecostal Diasporic Missions and Intergenerational Conflicts: Case Studies from Amsterdam and London
}

\author{
Bisi Adenekan-Koevoets \\ PhD Researcher, Humanities Department, School of Humanities and Social \\ Sciences, University of Roehampton, London, UK \\ adenekaa@roehampton.ac.uk
}

\begin{abstract}
Since the 196os, African-led Pentecostal churches have flourished in the UK and Europe, often identifying the evangelisation of White indigenous populations as a key missiological aspiration. This desire has not yet been realised, although by numbers and social engagement, African Pentecostals are making their presence known and returning conversations on religion to the public sphere in Europe. This article, based on case studies in London and Amsterdam, departs from established scholarship on 'reverse missions' by arguing that intergenerational conflicts within Nigerian-initiated Pentecostal churches in Europe are a significant obstacle hindering their missional aims. This qualitative study focuses on second- and subsequent-generation Nigerian migrants and their perceptions of the missiological and religious activities of the first generation, exploring intergenerational conflicts relating to leadership; indigenous beliefs/practices; gender/cultural norms, and missiological approaches. It argues that addressing these points of conflict will be an important tool for the missional success of African Pentecostals in Europe.
\end{abstract}

\section{Keywords}

first- and second-generation - inter-generational conflict - reverse mission - beliefs and practices - African Pentecostalism - African diaspora - Nigeria - Europe 


\section{Introduction}

The ubiquitous presence of African and specifically Nigerian Pentecostals in parts of Europe and the UK cannot be disputed. ${ }^{1}$ In major European cities, their Sunday worship services, with their colourful attire and high-volume worship, are variously a source of intrigue and annoyance to their European neighbours. They are in Europe to stay but their future is linked to their ability to achieve missional success within the wider European indigenous political, economic, and social structures in which their missionary efforts are conducted.

Scholars have observed for several decades that Nigerian Pentecostals are embarking on missionary endeavours within Europe to ensure their future embeddedness within host societies. Missional attempts by the first generation (FG) have been firstly through evangelising fellow Afro-Caribbean migrants; secondly, endeavouring to attract White European indigenes; and thirdly, through socialising their children, the so-called second-/subsequentgeneration ( $\mathrm{SG}$ ), into the Christian faith. After socialising them, retaining the SG within their churches has become a growing challenge among Nigerian and other African Pentecostals.

But why is this difficult? And if Nigerian Pentecostals are not able to retain their SG, what are their chances of successfully reaching indigenous White/ European populations, a key aspiration of 'reverse mission'? And why are these questions relevant to the future of Nigerian and other African Pentecostals in diaspora? Considering the markedly different life experiences and worldviews of the FG and SG, how do the SG perceive the missionary activities of the FG? How do their views differ from or resemble those of their parents? What are the various factors contributing to or hindering the success of intercultural evangelism, in the view of the $S G$ ?

These are questions that this paper seeks to address, drawing on my experience and qualitative research as a Nigerian Pentecostal woman who lives in both London and Amsterdam. This paper argues that the future of Nigerian, and African Pentecostal Churches in Europe, and academic narratives surrounding reverse mission, depends upon how these questions are addressed. This is significant because, as Caleb Nyanni (2021:6) argues, while there is a wealth of scholarship engaging "reverse mission" and FG African Pentecostals in Europe, there remains a dearth of engagement with the SG. This paper builds upon some recent studies that have emerged focussing on the SG's experiences as young African Pentecostals in Europe and America. While Nyanni (2021;

1 For simplicity, within this paper I use the term 'European' to include the UK and Western Europe. 
2018) studied the issue of spirits among Ghanaian youth in the UK, Adebayo $(2019 ; 2018)$ investigated religion and spirituality of Nigerian Pentecostal youth within the RCCG in England. Additionally, Reynolds and Zontini (2016:379-91) explored the transnational and diasporic identities of migrant youth in direct response to policy debates on their perceived marginalisation and social exclusion from the wider European societies.

\subsection{Methodology}

This paper is based on data collected through qualitative research in Amsterdam and London from 2017-2020, with case studies engaging the Redeemed Christian Church of God (RCCG), Living Faith Church Worldwide (LFCW, also known as Winners Chapel) and House on the Rock London (нотR). These are Nigerian-initiated denominations with their headquarters in Nigeria who maintain ongoing relationships through transnational networking. A parish of each denomination was selected in London and Amsterdam for comparative purposes, except in the case of нотR, whose Netherlands' branch closed during my research.

The study included extensive participant observation and in-depth, semistructured interviews with about 40 people representing different age groups, genders, and membership status. Three focus group discussions were also conducted. These include the Amsterdam group and the London (LKU) focus group, both of which were made up of only second-generation participants. The third is the RU focus group, also held in London, that selectively brought the SG and FG together to hear one another's perspectives. During this period, I immersed myself in these churches, participating in most of their activities and gaining insights into their engagements and ethos, in addition to the interview and focus group data. Finally, online and print church publications were also consulted. While much research on the theology and mission of African diaspora churches focuses on large congregations, ${ }^{2}$ this study instead concentrated on small congregations of between 20 and 150 Sunday worshippers. This is because most diaspora churches have small congregation sizes, as Burgess discovered with the RCCG in Britain (Burgess 2012:136).

As a researcher, my identity as a Nigerian Pentecostal migrant woman offered both benefits and challenges. While acknowledging my own possible biases as an "insider", this role also gave me greater access in some cases, as participants felt I was "one of them." Further, while current scholarship on African Pentecostals and "reverse mission" continues to be quite male-dominated,

2 See Cartledge et al. 2019; Coleman 2013:379; Knibbe 2011:471-87; Burgess et al. 2010:97-121; Ukah 2008. 
I am glad to add my voice to the growing number of African women engaging this important topic.

One of challenges in this study is that participants were in some cases hesitant to share their stories and experiences, particularly when it was critical of leadership. Therefore, participants were assured of anonymity. This was especially vital for young people, because among the Yorùbá, respect for elders is highly esteemed, and criticism, no matter how constructive, can be seen as disrespectful. With this guarantee of anonymity, the SG spoke comfortably and openly and were hopeful that telling their stories would elicit change within their churches. Pseudonyms are used throughout, except for a few senior leaders with their consent.

Participation was entirely voluntary, and participants all read and signed consent forms outlining the purpose of the study, the extent of their involvement, and their freedom to withdraw at any point. The interviews and focus group discussions were carried out in open and accessible locations chosen by participants. Ethics approval was obtained under the procedures of the university where the study was conducted. There were some challenges, including difficulty of access to interviewees, refusal by some to be interviewed, and in particular, logistical challenges of the Covid-19-induced lockdowns of 2020. Nevertheless, the voices and insights of the SG about why missions of the Nigerian diaspora Churches are "failing" are perceptible.

\section{Aspiration and Focus of Nigerian Pentecostal Churches Ministry in the Diaspora}

The first missional focus for Nigerian churches has primarily been other Afro-Caribbean migrants. This has been most successful within Nigerian independent Pentecostal megachurches like Kingsway International Christian Centre (KICC) and the Redeemed Christian Church of God (RCCG), as is the case in some of their larger parishes such as Jesus House for all Nations. ${ }^{3}$ In these churches, some of which have been described by Adedibu (2013:416-23) as "migrant sanctuaries or repositories of large ethnic churches," they see minimal need for contextualisation because a large proportion of the congregation are first-generation African and Caribbean migrants who are conversant with

3 A parish in the RCCG is a congregation or unit of administration of as little as ten to as large as 3000 regular attendees. It is different from the parish system in the UK which is a welldefined geographical unit representing populations of less than 100 to about 70,000 and represents the tier of local government that is closest to the electorate. 
"home" beliefs and practices. The main opposing voices are those of the growing population of the second-generation.

The second missional focus is the narrative of missionizing White Europeans. This is a concept commonly referred to as "reverse mission," discussed both by Nigerian and other African church leaders as well as segments of the academia (Klair, 2020). Some suggest that Africans are succeeding in evangelising White Europeans, citing as an example the Embassy of the Blessed Kingdom of God for All Nations (E BKG) in Kiev, where Sunday Adelaja, a Nigerian pastor, leads an all-White church (Asamoah-Gyadu 2005; Wanner 2004). However, as Asamoah-Gyadu (2006:74) also notes, EB KG is not paradigmatic of African diaspora churches and should not be taken as such. Others describe "reverse mission" as rhetoric designed to give migrants a measure of relevance within western societies. Many scholars remain cautious with the concept, describing it as an evolving process that requires nuance to measure whether it can be considered a success, considering migrants' engagement with social activism. ${ }^{4}$

The most important aim of the "reverse mission" narrative remains the reevangelization of Europe and the rest of the West based on the notion of the decline of the western Church. This decline, both in membership and societal relevance, is true of especially mainline churches like the Church of England and the Roman Catholic Church in Britain, and the Protestant and Roman Catholic churches in the Netherlands (Voas and Bruce 2019; Brierley 2017; Knippenberg 2006:324). Based on this decline, and their self-perceived "call" to global evangelism, African Pentecostals are convinced of their role in reversing this trend of declining church membership and participation. "Reverse mission" as conceptualised by Africans - as a need for revitalisation of the West as the former heartland of Christianity - connotes an intrinsic mandate for global evangelism. However, African Christianity as the embodiment of an intersection between mission-based Christianity, indigenous cultures, and contemporary African cultures, without contextualisation, problematises the practice of "reverse mission" within European contexts that are different from migrants' countries of origin (Obinna 2014:78). The irony remains that after more than half a century in Europe and America, "reverse mission" remains an aspiration rather than an achievement. As we will see, the second and third generations of Nigerian descent have their own reservations about how their parents and grandparents envision and execute their missionary agenda.

4 See, for example, Olofinjana 2020:58; Wariboko 2014:246; Währisch-Oblau 2012:20; Koning 2011:11; Freston 2010:153-74. 
Beliefs and practices are crucial in the relationships of these churches, both between the leaders and members of the churches and externally with host societies. Although closely related, beliefs have to do with how people think and the factors influencing those thought patterns, while practices are more tangible and enforceable, since they emerge from people's thought systems (Parekh 2006:145). The fact that beliefs can be influenced by exposure to new or different knowledge and ideas means there is possibility for change in beliefs and therefore in conduct (Nyanni 2018:244; Parekh 2006:145). In other words, the way that the individual practices his or her beliefs, not just in a worship service, but in everyday living, can be altered with access to new information. $\mathrm{Nel}$ (2015:1) adds that it is not just related to the private lives of the individual but also the communal life of the church community. African Pentecostalism teaches adherents, based on the Bible, to be "doers of the word and not just hearers" (James 1:22 NKJV). This alludes to the need to act on their beliefs in their everyday living and to "stand out" from their environment. In the remainder of this article, I will discuss my findings in two streams: 1) how mission (evangelism and social action) is perceived and executed by the different generations, and 2) how practices like prayer, worship, and leadership are conceived of and executed by the FG and the tension this creates with the SG.

\subsection{Mission as Evangelism}

While some participants defined mission in terms of church planting and establishing branches of their denominations in different parts of the world, others defined it in terms of the overall objective of the church, while a few included acts of community engagement. Terms such as evangelism, conversion, or "soul winning," are commonly used to refer to acts of soliciting new members and are carried out using the following strategies: street evangelism using fliers, person-to-person contact, print and social media, and church planting. Among all the case studies, street evangelism (which involves talking to strangers on the street and distributing fliers) was a common strategy. As defined by pastor Deolu of HотR, evangelism is "going out and talking to the public about faith, it is the actual feet on the ground." This is a description that was common among the participants and most of them did not conceive of mission as being a combination of evangelism and social action.

In making a distinction between mission and evangelism, I refer to Währisch-Oblau (2012:225-6), who describes mission as a goal-oriented

5 Deolu, “Interview," London, 15 February 2019. 
interaction between a group of believers (whether individuals or a church congregation) and those outside of this group (whether individuals, communities, societies or governments). On the other hand, evangelism, which is an aspect of mission, involves the active recruitment of members who become committed to the tenets of the recruiters.

The other aspect is social action, and the definition by Tunde Balogun, a member of the RCCG Jesus House London Social Action Group, suffices for this article. Balogun (2013:2) defines social action as "how we promote social change by finding solutions to the common problems within our communities." In other words, identifying needs and rendering support to meet those needs; and Jesus House has been at the forefront of civic action generally within the UK.

Towards the achievement of evangelism, Pentecostals are expected to share the gospel anywhere they go with neighbours, classmates, colleagues, friends, family members and people they meet during their daily lives without fear. They believe that they have been called by God to be witnesses in the power of the Spirit in obedience to the instruction of Jesus in the Bible (Matthew 28:19). As theologian Veli-Matti Kärkkäinen (2018:10-11) notes, one of the most central theological motifs for Pentecostals is eschatological enthusiasm and urgency of mission. They bring a remarkably different dimension to the understanding and practice of evangelism since they come from contexts where evangelism is intrinsically interrelated to discipleship. For these African Pentecostals, evangelism remains the central identity of any church and a primary goal of theological training, and they continue to evangelise despite facing difficulties. These include rejection, aggressive responses from members of the public, reluctance and inability of church members to participate, and limited success of their missional agenda. Information from my data indicates that street evangelism is a common evangelistic practice among Pentecostals in Nigeria and is something they have carried with them as they migrated and which they replicate in the European public domain even though there are considerable cultural and social differences.

For example, despite the ineffectiveness of leafleting, Andrew, a deliverance pastor of RCCG in London, stated that members of his parish still drop evangelistic fliers through people's letter boxes especially in high density housing estates. ${ }^{6}$ нот R is also involved in regular street evangelism, although also engages in some community activities. In Amsterdam, RCCG participants feel compelled to use fliers because as Dele Olowu, special assistant to the RCCG General Overseer and assistant general overseer for Europe Mainland Region

6 Andrew, "Interview," London, 7th December 2017. 
explained, "the lack of proficiency of the Dutch language makes conversation with people on the street difficult so all that can be done is to give out fliers." Similarly, Tola, a member of one of the small RCCG parishes in London called RCCG-LKP, admits that even when she distributes the fliers, only very few people accept it and even fewer visit the church. ${ }^{8}$ During participant observation sessions with RCCG-LKP, I experienced the same reactions on the streets and no visitors came to the church as a result of street evangelism in the two-year period. Street evangelism is also a task in which the whole church is required to be involved, but I observed that very few people participated and there were times when it was only the minister in charge that attended.

William is about 55 years old, male and an itinerant evangelist based in Amsterdam who acknowledged that: "the percentage of people who will look at it [fliers] is between $1 \%$ and $5 \%$. But because of the testimony we have had that people go back to pick up tracts that had been lying around and the Holy Spirit work[ed] on their heart, they trace the address or make contact. We should not lose sight of sharing tracts. Let us see it as a spiritual thing that we give, backed up with prayers." ${ }^{9}$

Like William, most of the older respondents insist that leafleting is relevant because these are "spiritual" documents. They believe that praying over an ordinary document can infuse it with divine power and turn it into a text that the Holy Spirit uses to work on recipients' hearts. This way, prayer as a transcendental activity with the unseen realm has a significant impact on their belief and expectations regarding evangelism and how they relate with their environment. As Droogers (2003:271) argues in his three-dimensional power model of relationship by religious communities, belief and its practice by a religious community influence how that community relates to its surrounding environment.

This sort of reference to prayer and the Holy Spirit by the FG are aspects of spirituality that do not resonate with the SG. All the young people in this study were passionate about their Christian faith. They also believe in the power of the Spirit and prayers. One of them teaches Sunday school classes in her RCCG parish while another leads the children's Sunday school. They, however, argue that their parents tend to "over spiritualise" issues that they feel need a rational approach. Evangelism cannot be done without the help of the Holy Spirit, but wisdom also dictates that if an approach is not productive, it needs to change. As one Nigerian Baptist minister noted, "Transplanting mission strategies from

7 Olowu, "Interview," London 9th June 2018.

8 Tola, "Interview," London 22nd June 2018.

9 William, Interview: Amsterdam, 22nd April 2018. 
Nigeria will not work here [the UK]. I think the mission strategies have to change. Whereas I can preach on the bus in Nigeria, here people would probably spit at you or tell you to shut up and say, 'you are disturbing my peace."'10 There are further generational differences in approaches to and expectations from evangelistic activities. Participants at the LKU focus group in London are opposed to leafleting, seeing it as:

An imposition on 'people you don't even know.' With evangelism the leafleting way, you come across someone on the street and you come across 'heavy' [...] It's like when a salesperson is trying to sell you something really quickly on the street. If you don't want to stop for that, why would you stop for someone else? When I think of evangelism, I think of people advertising their church as opposed to a relationship with God which is what it is about. Maybe the reason why we are not getting through to people is because our approach is like a business; we are trying to gain numbers in a church as opposed to getting people to heaven. ${ }^{11}$

Participants in the Amsterdam focus group indicated a preference for building friendships instead of seeking to "convert people randomly on the streets" and preferred discussions that respect the beliefs of "the other."12 There were also references to modes of communication that respect the listener's privacy and which seek to engage rather than to impose. For young people, it is about building relationships with people and then talking to them about a relationship with God rather than a quick message of heaven and hell.

\subsection{Mission as Social Action}

Jesus addressed the holistic needs of those he came across because he did not separate spiritual from everyday needs (Matthew 9:35-38), but resolved spiritual, emotional, physical, and material needs. Pentecostals' understanding of the gospel is the same, although, as observed during this research, most Nigerian diaspora churches are not involved in community activities. Participants admit that community engagement is a demonstration of the "Great Commandment" to love one's neighbour and it could be an attractive entry point for evangelism, but they are limited by financial, human, and social capital. Pastor Temi leads House on The Rock London (нотR) and he admits that his church engages in some community projects: "To resonate with the [white] indigenous people, that we are not just singing and praying but doing

\footnotetext{
10 Revd Michael, Interview: London 16th March 2017.

11 SG focus group participants LKU, London 2nd March 2018.

12 SG participants, Amsterdam focus group 26th August 2018.
} 
practical things. НОтR is involved in community efforts by organising youth activities, music events and concerts and contributing to the local food bank. This is within the manpower available to the church."13

He acknowledges that the challenges of limited resources and difficulty of getting Caucasians into their churches lead some African-initiated churches to unconsciously give up and become more focused on the pastoral care of their members rather than on social action within host communities. As Cartledge et al. (2019:214) found, similarly, in the case of well-funded mega branches and churches, involvement in outward-looking social activities was smaller in scale compared to activities that focus internally on members. They attribute this to the identity narrative of diaspora churches and the need for self-betterment of their members. Lack of resources may therefore be one of many reasons for the limited external focus of some of these churches, especially the smaller ones.

Regarding social action, young people argued for change towards more consistent and effective social activism in Europe rather than just pastoral care of members. Adam, from Amsterdam focus group, noted that:

They are doing absolutely zero in that respect. We are in the centre of Amsterdam, which is the centre of smoking weed, teenage pregnancy and all; in the 4 years that I've been here, I don't think they've ever talked about smoking once or pregnancy, which is more important than tithe. If they talk about things like that, people around here will come because it is their everyday life. The church ... should also give back. You want to see that the church is giving to someone else. ${ }^{14}$

Adam was pointing to his desire for the leadership of his parish to identify needs within its host community and be more active in providing solutions. This is what Poloma (2003:140-1) refers to as "godly love." She argues that being touched by the love of God through the Holy Spirit produces love for God in believers and by extension a love for others, which propels them to engage in works of compassion (Poloma and Hood 2008:115-16). The SG argue that if the church gets more involved in social activities, it will become more relevant to its communities, which could enhance its missional aspirations.

As noted by participants, there is also a need to prioritise financial spending and the injection of new ideas regarding community engagement. Often, some of these churches have rules and regulations that can stifle choices surrounding the allocation of funds. Jonathan is a youth leader in one of the RCCG

13 Temi, "Interview," London 24th November 2016.
14 Adam, Amsterdam focus group 26th August 2018 
parishes and he explained that spending on social action is difficult because of church accountability and monitoring system:

[The church wants] more to be spent inside rather than outside the church. Parishes are also expected to remit some of their income to the central office. In that regard, expense on social action should be balanced by tithes and offerings from new converts [results of social action]. It is like an investment and when you invest you expect returns, but if there is no increase in the number of people coming to church then the administrative officer will raise an alarm. ${ }^{15}$

This points to the priority of some churches on funding pastoral care of members and other activities of the church organisation rather than social action. For example, Dele Olowu holds the very senior position of Assistant General Overseer of the RCCG, and he describes it as strategic to focus internally on members who are trained and understand the principles of giving and give generously rather than others outside who need to be convinced to attend or give to the church. For small congregations with little income, achieving spending requirements can be challenging and therefore they are more internally focused.

\section{Second-Generation Critiques of Nigerian Pentecostal Missionary Activities}

We have indicated that part of the focus of Nigerian Pentecostal churches in diaspora is this concept of "reverse mission." Yet the same churches are struggling to maintain their European-born Nigerian members, who often share the same cultural views as the indigenous white people that their churches are aspiring to reach. It is the critiques of these second and third generations that engage our attention here.

\subsection{Mission and Contextualisation}

Second-generation participants in this study are agitating for the contextualisation of some of their parents' beliefs and practices but are held back from being assertive by prevalent Yorùbá traditional norms of respect for elders and those in authority. They refer to prayer styles and contents that are needs-based and sometimes aggressively articulated or worship that is characterised by loud singing, exuberant dancing, and highly emotive. These result in situations

15 Jonathan, "Interview," Amsterdam 29th April 2018. 
where Christian and Nigerian traditional religious practices are occasionally intertwined, thereby creating church communities that are centres for the "re-creation of Yorùbá/Nigerian/African dialectics" (Adedibu 2013:417). Young people see some of the practices and parts of the liturgy of the church services as recycled religion and argue that information should be made more inclusive. However, effecting dialogue for change is fraught with challenges which in turn leads, not only to frustration and grumblings internally, but in extreme cases, to the SG leaving the churches. This is one of the major challenges confronting the Nigerian-initiated churches in my study. It is important to note that some large parishes, led by individuals with cosmopolitan capabilities, who are versatile with global networks and able to adapt to different contexts, fare better at retaining their young ones.

Perpetuating beliefs and practices which do not resonate with young people and some of their non-African friends is problematic. Adam noted, "I think I have brought ten of my white friends and they like the music, but they never come back."16 Issues they point to include the loud music and aggressive prayers, which they find difficult to engage with. Also, the SG claim that the sermons preached do not address issues that are relevant to young people. Joke, a White Dutch female participant of the Amsterdam focus group and partner of Justin, a male Nigerian participant comments: "Their messages could be way more practical. For example, after Hillsong, ${ }^{17}$ when we go home, we still think about things and discuss the issues raised, but when I leave here [the RCCG], I really don't understand the message."18 Non-Africans like Joke, who describes herself as not yet a believer, but willing to attend the church, would seem to be exactly the type of person for whom greater contextualisation of some practices would be beneficial.

Debby, an SG Nigerian and daughter of an expatriate, left Nigeria at the age of nine, and has lived in different parts of the world because of her father's job. She offers the following reflections:

They have to make what they [the FG] talk about less complicated ... They don't talk about the first thing that will come to your mind like teenage issues ... only stuff in the Bible. They don't think about all the social influence in the world today. Everything has been in the Bible since $2000 \mathrm{BC}$, they don't relate it, they just leave it there. All our teacher talks

\footnotetext{
16 Adam, Amsterdam focus group, 26th August 2018.

17 Hillsong is a megachurch which describes itself as a contemporary Christian church. It was founded by Brian and Bobby Houston in 1983 in Sydney, Australia, and claims an average global weekly attendance of 150,ooo people. See https://hillsong.com/about/.

Joke and Justin, participants, Amsterdam focus group. 26th August 2018.
} 
about are stuff that happened in the late 198 os and 1990s and this is 2018 . There is the internet, social issues, elaborate stuff to go through ... what she [the teacher, who is also her mother] learnt when she was our age and we must learn the exact same things. ${ }^{19}$

Debby voices the views of many SG participants in London and Amsterdam. Their emphasis on the acceptance and openness they experience in churches like Hillsong compared to their parents' churches was shared by most. The tendency of FG leaders not to familiarise themselves with contemporary discourses and relate their spirituality appropriately is problematic. The SG have friends who are atheists, Buddhists, Muslims and they want the church to reach out to them using different strategies. When their non-African friends attend church, they want them to hear relatable things.

\subsection{Mission and Leadership Styles}

Another important source of frustration in my case studies is the leadership style, as the youth experience it. It is leadership that can be described as hierarchical in its organisational structure. Pastor Omawumi established нотR London in 1996 and then had to resign due to disagreements with нотR Nigerian headquarters on issues relating to leadership style. He described the leadership of Nigerian diaspora churches as: "the very big head and very small body type, the kwashiorkor kind of depiction because that is the reality of our systems of leadership in the diaspora. I think that will invariably affect the way missions are being planted." 20

In these churches, leadership is modelled after the Yorùbá indigenous administrative system of stable, progressive, smooth, and relevant hierarchy. This is a system that the Yorùbá have found beneficial in secular life and have therefore transferred to the church (Awoniyi 2014:4). Within this structure, power is concentrated at the top and trickles down to the rest of the body. It is, however, important to note, according to Adogame (2013:80), that the hierarchical and organisational structures of Pentecostal churches in Africa and the diaspora are very diverse. There is, therefore, a need for caution in generalizing their polities and administrative structures. The following are my observations and young people's perceptions of leadership within the church and the impact it has on them.

The SG were explicit about the role of leadership styles and power imbalances in the implicit intergenerational conflict within their churches. In Yorùbá tradition, the concept of Omoluabi or an "ideal being" forms the basis

19 Debby, Amsterdam focus group 26th August 2018.

$20 \quad$ Omawumi, "Interview," London 11th February 2019. 
of child upbringing (Akínyemí, 2015:231). Omoluabi is a person of good character, and one identifier is of someone who has respect for elders and those in position of authority (Akanbi and Jekayinfa 2016:15). In these Yorùbá-initiated and dominated churches, this culture is pervasive. It is often a setting where leaders do not anticipate or accept dissent or criticism from a young person. Sade, an undergraduate, is a female SG member of RCCG-LKP. She illustrates this generational difference in this excerpt where she refers to the pastor in the masculine gender and as an older man:

you as a young person cannot go to the leadership with what appears to be a criticism. To go to the pastor and make suggestions about how things should be done, is difficult. [When] the pastor is young and trendy, it is easier to relate to him. Auntie and uncle are here so even if I have something to say that will progress the church, I don't feel comfortable to say it. ${ }^{21}$

Sade goes on to express the frustration of young people like herself about not being taken seriously by the adults and how they are expected to respect Yorùbá traditional norms which young people sometimes do not understand or agree with:

[I]t's always like you are the child, so stay in your place. They tell you we want the youth to take over, we want people to speak up their minds but what have you done with the times they have spoken their minds or are they just children? They need to make up their minds, are we just children or the ones that they expect to take over. You are told to "respect your elders; call them auntie" though in English language, auntie is my mother's sister, which this person is not, but you are expected to do that. Things like that have become the norm ... In church we get that kind of fear with our respect, and I find that contradictory. ${ }^{22}$

What is being articulated here is the hierarchy of authority that a young person goes through to get an idea across. It is made complex with respect for tradition where seniority is of crucial importance and the opinion of older men are given precedence (Eades 1980:53). Although gerontocracy is often applied to political systems, it is not restricted to socio-political thought alone. It also refers to the traditional African respect for the authority of elderly persons for their wisdom, knowledge of community affairs, and "closeness" to the

\footnotetext{
21 Sade LKU focus group 23rd February 2018.

22 Sade, "Interview," London 7th December 2018.
} 
ancestors (Dei 1994:13). Among the Yorùbá, there is a premium on old age, and they traditionally believe that in all situations, elders are wiser and can ensure the resolutions of all challenges (Delano 1979:38-9).

John is a young RCCG assistant pastor (AP) who believes that hierarchic leadership can be beneficial in that it gives clarity of leadership. However, "it can also be a disadvantage because it creates a challenge when one needs to effect a change that appears contrary to church policy or if there is a disagreement with one's superior." ${ }^{23}$ RCCG Amsterdam youth leader Jonathan echoes similar sentiments, arguing that it is time for "a change of baton from Moses to Joshua." He also notes that there is an urgent need for contextualisation of some doctrines so that growth will not be impeded."24

Naomi is a White Dutch lady and a former RCCG assistant pastor: "I understand that God speaks but Jesus worked on earth with 12 disciples. He mixed with everybody. He touched people; he healed the people. He sat on the boat between people and touched people ... he should be our example ... how we should interact with the world around us." 25

Hierarchic leadership can stifle creativity and growth; it can perpetuate mediocrity with the circulation of the same ideas, and people and can turn long-standing leaders into authoritarian leaders who confuse divine and human instructions. Naomi emphasises the need for servant-leadership as modelled by Jesus. She suggests that Nigerian-origin churches do not yet fully follow Jesus' example which she believes should define the relationships of the church internally (with the congregation) but also with its host communities.

The perpetuation of this type of centralised leadership in the diaspora is a carry-over, according to Omawumi: "The governance of the church in diaspora is reflective of the leadership style in the nations from which those churches come. They operate a centralised form of leadership which often has a detrimental effect on mission practices in the diaspora." ${ }^{26}$ This top-heavy power arrangement remains effective among the Yorùbá because it is familiar and culturally accepted. This is, however, difficult to efficiently replicate in the West because the culture is different.

Some leaders and members believe that the transnational networking, including the exchange of pastors from Nigeria, is part of an effort to monitor what diasporic pastors are doing and to ensure that they are adhering to set standards. Pastor Omawumi questioned the policy of bringing pastors from Nigeria to lead diaspora branches and wondered if the aim is to perpetuate

\footnotetext{
23 John, informal discussion, London 8th March 2020.

24 Jonathan, "Interview," Amsterdam 29th April 2018.

25 Naomi, "Interview," Amsterdam 18th April 2018.

26 Pastor Omawumi, "Interview," London 11th February 2019.
} 
their own style in a foreign country or for missionary purposes: "Sometimes our culture and tradition are so strong that they hinder or drown out the larger mission that Jesus had in mind. The failure to realise that we are dealing with a different culture, a different group of people in a post-Christian environment, could impact migrant Pentecostal mission negatively. On spiritual matters our people can be quite emotional but here they are quite cerebral, so a more representative leadership culture is more needful here than a domineering one."27

Some FG migrants are aware of the issues raised by young people but some of these rules are so culturally embedded that it will be a herculean task to eradicate or change them. Pastor Ade, a 55-year-old male participant of the London RU focus group, commented on the needs-based focus of the prayers, like for "papers" [legal resident documents], or against witches, which is often confusing for the SG. He narrated how exasperated his (then) young daughter used to be when listening to these kinds of prayers. When the daughter learnt what "papers" meant, she wondered why they did not simply request these documents from the Home Office. That daughter is an adult now and once she left home to attend university, she joined another denomination and did not return to her father's church. ${ }^{28}$ According to SG participants of the LKU focus group: "A 65-year-old pastor who did not go to school in this country [Britain] at all does not know what is happening and cannot effectively communicate with young people born in this country."29

Pastor Olowu is a member of the RCCG Board of Trustees. He is also a retired professor of international development who has lived in different parts of the world for over twenty-five years. He argues that African churches need to adapt their teachings and make them more relevant to the issues that confront young people. He suggests that some of the issues they face are almost taboo and hardly discussed on the pulpit, and gives the following example:

I visited a youthful church and what I found to be different is the things they were talking about. The pastor was talking about sex, and I realised that this is what the younger generation want to hear, whereas we would think that this is not an issue to be talked about in a church. But this is what the young people are struggling with. The pastor afterwards told me they talk about three big things which most conventional churches don't talk about. These are sex, money, and peer pressure. ${ }^{30}$

\footnotetext{
27 Pastor Omawumi, "Interview," London 11th February 2019.

28 Ade, participant, RU focus group, London, 2nd March 2019.

29 Participants, LKU focus group, London, 23rd February 2018.

$30 \quad$ Pastor Olowu, "Interview," Amsterdam, 29th August 2018.
} 
This is insightful because Olowu is of an older generation usually known for conservative views on Christian beliefs and practices, but his more inclusive attitude may be attributable to his level of international networking and exposure. His comment alludes to a church that listens and attempts to communicate the gospel relevantly and effectively to young people.

It was, however, not all negative because more than 80 percent of the SG acknowledge that the church has a "family feel" that you do not get in a church like Hillsong. Adam, an SG member of RCCG in Amsterdam, says: "One thing you can't take away from our church is that it's a family, it might not be a good family but it's still family. Because even though you choose to go to Hillsong, there are still some things that you miss there. The ideal would be an African church with a Hillsong vibe." 31

There is a sense of identification with a community that gives one the confidence to, for example, meet someone and share one's heart with them and know that they will be sympathetic. Adam will willingly drive someone home after a worship service if needed, even if it was out of his way, "because it's the African thing to do." Members also offer each other economic and social help needed when living as migrants in a foreign land. Migrant churches have always functioned, not just as religious communities, but also as hubs for the restructuring and transformation of their members' identity, belonging, and self-worth (Glick Schiller and Karagianis 2008:270; Haar 2001; Van Dijk 1997:135-159).

Significance and Implications of this Study

The question is, if these SG Nigerians who are born and bred in Europe have reservations about the missional approaches of African Pentecostal churches and are reluctant to stay, how can these churches hope to attract White Europeans, and what does the future hold for them in the long run? Within these circles, one argument that we hear regarding this lack of growth is that the indigenous white individuals are to blame for being "hard-hearted" to the gospel (as understood and preached on Nigerian terms). But our study reveals a different narrative: that perhaps internal structures, beliefs systems, leaderships styles, and approaches to missions are important factors undermining Nigerian and African Pentecostals' missionary aspirations of reaching white indigenous Europeans and creating multi-cultural and multiracial churches. So, what are the implications and significance of our study?

31 Adam, "Interview," Amsterdam 6th August 2018. 
Contextualisation has long been a key part of missiological discourse, yet for some reason there are unspoken assumptions and perceptions that the term only applies to mission fields in the global South, but not in Europe or North America. The alternative narrative emerging from SG Nigerians within our study seems to suggest that the future of Nigerian Pentecostalism in Europe and the UK, with particular regard to their missiological aspirations, is contingent on their ability not only to contextualise the Christian message but also their approach to mission in the diaspora. Scott A. Moreau (2012:36) defines contextualisation as the process where the forms, content, and praxis of the Christian faith are adapted to specific contexts. This enables the gospel to be adequately communicated to the hearts of people of diverse cultures. "The goal is to make the Christian faith as a whole - not only the message but also the means of living out our faith in the local setting - understandable." The theologian Rodrigo Tano (1981:10) goes further to argue that contextualisation calls for a discerning of the times, involvement in one's context, and participation in the ongoing mission of the church, wherever that may be.

Of course, contextualisation must be grounded in scripture, rather than replacing Bible teachings with cultural beliefs. And good contextualization uses theology, anthropology, sociology, linguistics, communication, psychology, economics, and politics to offer a comprehensive view of a local setting (Tano 1981:10). To have missional aspirations to reach out to indigenous people, whether of African or European descent, with a religious vocabulary and symbolisms that your audience cannot comprehend or access, is not only tragic but an affront to the missiological implications of the Christian doctrine of incarnation. As one Nigerian SG interviewee put it: "I wasn't there [in the Sunday service] today but if I was, I wouldn't understand anything even though I have been a Christian for all my life. They have to make what they talk about less complicated [...] All they talk about are the bad things that we need to correct. ${ }^{32}$

When the writer of the gospel of John wrote "the Word became flesh and made his dwelling among us. We have seen his glory, the glory of the one and only Son, who came from the Father, full of grace and truth" (John 1:14), he was drawing attention to a missionary God who took on human flesh in the person of Christ, within a specific time and place, to live in specific cultures, so that God could be known within a specific cultural context. Commenting on the missiological implications of the doctrine of the incarnation, Dawson notes: "Our redemption depends on the reality that the eternal Son of God came to us as a man. If he did not come fully down, then we are not fully saved. 
But the incarnation is the news that Jesus became what we are, fully entering our lost and forsaken condition, taking up into himself our very humanity. God crossed the gap between us and himself" (Dawson 2004:6). It is clear that the challenges that SG in Amsterdam and London face within their African Pentecostal churches that are causing them to leave in significant numbers require urgent attention. Until the Nigerian and African Pentecostal leaders adapt and contextualize their messages, leadership style, and understanding of mission, in order to fill the gap that exists between FG and SG, the future of these churches seems bleak. "Christianity is a religion in transition. As part of a constantly changing world that progresses, develops, renews, and reinvents itself, Christianity is subject to the changes of human cultural and social existence" (Pears 2010:12). It is this missiological elasticity that SG are demanding. And for scholars of African Pentecostal "reverse mission," the ways in which the FG leaders respond to this challenge ought to be a greater focus of attention.

\section{6}

\section{Looking Ahead: The SG as Missiological Resource}

We have already indicated some theological, missiological, sociological and cultural implications that emerged from this study, some which go beyond our focus here. The significant findings that this study has identified are intergenerational conflicts on issues such as gender, leadership, power dynamics, and cultural norms that have been imported from Nigeria, which do not resonate with the SG in European contexts, and which hinder the missional aspirations of some Nigerian Pentecostal churches in London and Amsterdam. This article has articulated, through the voices of participants, that the secondgeneration do not share some of the cultural and religious convictions of their parents, causing them to variously step back from missional engagement or leave these churches entirely. Both scholars and church leaders as a matter of urgency and necessity need to pay heed to this and initiate positive responses through academic study and pragmatic action.

What are some practical steps to be taken? First, it is apparent that the Nigerian churches do not perceive the SG as any more European than African. Some of the SGs were born in Europe and some migrated as young children, but all of them grew up and were educated in Europe, so they can best be described as Afro-Europeans, with worldviews that are neither African nor European but a blend of both. A vital question is whether they can express this distinct worldview within the Nigerian church environment. This is a missiological and theological challenge that both scholars and African church leaders should pursue with reflexivity, openness, and humility. Without 
recognition of the SG as Afro-Europeans with unique religious and cultural expressions, it becomes difficult for the FG to achieve their "reverse mission" agenda. However, the flipside is that the SG may hold important keys for these churches' cross-cultural missional success. The fact that the SG share similar worldviews with their white indigenous counterparts make them uniquely equipped to relate with them and ultimately further the mission aspirations of the Nigerian churches, if given the leadership and authority to do so.

Building on this, African Pentecostal diasporic church leaders wanting to take this seriously and to benefit the most from their bicultural SG members will need to begin giving the SG greater leadership responsibilities, listening to their concerns, and letting them guide many of these initiatives. If leafletting and street preaching are not effective in a European context, what suggestions do the SG have for contextually relevant missional engagement? We have heard from some of them here; and it will be for church leaders to continue these discussions in their own parishes, while putting the SGs into leadership positions will enable the churches to take their global mission forward.

Next, scholarly discussions on "reverse mission" have been extensive, and it is an important discussion. However, this study indicates that there is a different way to envision research on "reverse mission." While a lot of scholars and practitioners focus on the external challenges to the achievement of these missional objectives, this study shifts the focus and discovers that in fact, internal issues within these churches are often hindering their missional aspirations. Once again, this may be seen as good news in the sense that internal issues are much more readily within one's control to change. While these churches cannot readily change the cultural contexts into which they have relocated, if they are prepared to engage with these internal challenges, they may well see significant progress with their missiological aims.

Finally, as a Nigerian Pentecostal woman who resides in both Amsterdam and London, the writer is aware of the difficulties these missiological contexts present to African church leaders, who often desire to draw strict boundaries separating the church from wider societal norms and practices. But irrespective of how doctrinally "pure" the church may want to appear; theology must always have intellectual and cultural relevance if it is to be understood and carried forward by the next generation. If we wish to pass on the baton of mission and ministry to the next generation, heeding their reservations is significant. Mission is inter-generational, and although it is commendable that the FG was able to successfully establish these churches despite the various crises they faced as migrants, it is important that they develop succession plans to hand over to the younger generation. This is not to suggest that the FG's missiological approach is only negative, or that the SG's have worked out 
all the answers! The SG will have their own missiological challenges in years ahead as Afro-European Christians, if they do stay in the church. Rather, this should simply be seen as a natural working out of Paul's missiological advise in 1 Corinthians 3:6-8: "I planted the seed, Apollos watered it, but God has been making it grow. So, neither the one who plants nor the one who waters is anything, but only God, who makes things grow. The one who plants and the one who waters have one purpose, and they will each be rewarded according to their own labour."

\section{References Cited}

Adebayo, Racheal (2019). "Distinguishing Between Religion and Spirituality: Listening to Teenagers Within the (RССG) Pentecostal Churches." Journal of the European Pentecostal Theological Association, 39(1): 79-94.

Adebayo, Racheal (2018). The Religion and Spirituality of Black Churchgoing Teenagers $\mathrm{PhD}$ thesis, University of Warwick.

Adedibu, Babatunde A. (2013). "Reverse Mission or Migrant Sanctuaries? Migration, Symbolic Mapping, and Missionary Challenges of Britain's Black Majority Churches." Pneuma, 35(3): 405-423.

Adogame, Afe (2013). The African Christian Diaspora: New Currents and Emerging Trends in World Christianity. London: Bloomsbury.

Akanbi, Grace Oluremilekun and Jekayinfa, Alice Arinlade (2016). Reviving the African Culture of 'Omoluabi' in the Yoruba Race as a Means of Adding Value to Education in Nigeria. International Journal of Modern Education Research, 3(3): 13-19.

Akínyemí, Akíntúndé (2015). Orature and Yorùbá Riddles. London: Springer.

Asamoah-Gyadu, J. Kwabena (2005). "An African Pentecostal on Mission in Eastern Europe: The Church of the Embassy of God in the Ukraine." PNEUMA:The Journal of the Society for Pentecostal Studies, 27 (2):297-321.

Asamoah-Gyadu, J. K. (2006). "African Initiated Christianity in Eastern Europe: Church of the 'Embassy of God' in Ukraine." International Bulletin of Mission Research, $30(2): 73-75$.

Awoniyi, Peter Ropo (2014). "Yorùbá Cultural Approach to Justice and Peace and its Influence on the Church in Southwest Nigeria." Ogbomoso Journal of Theology, 14(2).

Balogun, T. (2013). Some ideas for social action projects, in Starter Guide to Social Action: How to be Salt and Light in Your Community. RCC G Social Action Group.

Brierley, Peter (2017). "Immigrant Churches in Britain." Available at: https://static1 .squarespace.com/static/54228eoce 4bo5991oe19e 44e/t/5a159249odg2971bb c43a3c1/1511363146964/CS 3 +Page+16.5+Immigrant+Churches.pdf, accessed 2oth April 2020. 
Burgess, Richard, Kim Knibbe \& Anna Quaas (2010). "Nigerian-initiated Pentecostal Churches as a Social Force in Europe: The Case of the Redeemed Christian Church of God." Penteco Studies, 9(1): 97-121.

Burgess, R. (2012). "African Pentecostal Growth: The Redeemed Christian Church of God in Britain." In David Goodhew, ed., Church Growth in Britain:1980 to the Present. London: Routledge, 127-143.

Cartledge, Mark J., Sarah Dunlop, Heather Buckingham, \& Sophie Bremner, eds. (2019). Megachurches and Social Engagement: Public Theology in Practice. Leiden: Brill.

Coleman, Simon (2013). "Only (Dis-)Connect: Pentecostal Global Networking as Revelation and Concealment." Religions, 4(3): 367-39o.

Dawson, Gerritt (2004).Jesus Ascended: The Meaning of Christ's Continuing Incarnation. London: T\&T Clark.

Dei, George J. Sepha (1994). "Afrocentricity: A Cornerstone to Pedagogy." Anthropology and Education Quarterly, 25(1): 3-28.

Delano, Isaac O. ([1983], 1979). Òwe L'esin Òrò: Yorùbá Proverbs - Their Meaning and Usage. Oxford: Oxford University Press. Note: earlier publications include 1968, Nigeria: Oup Nigeria.

Dijk,RijkA.van(1997)."From Camp to Encompassment:Discourses of Trans-subjectivity in the Ghanaian Pentecostal Diaspora." Journal of Religion in Africa, 27(2): 135-159.

Droogers, André (2003). "The Power Dimensions of the Christian Community: an Anthropological Model." Religion, 33(3): 263-28o.

Eades, Jeremy Seymour (1980). The Yorùbá Today. Cambridge: Cambridge University Press Archive.

Freston, Paul (2010). “Reverse Mission: A Discourse in Search of Reality?" PentecoStudies, 9(2):153-174.

Haar, Gerrie, ter (2001). Halfway to Paradise: African Christians in Europe. Nairobi: Acton Publishers.

Kärkkäinen, Veli-Matti (2018). "Mission in Pentecostal Theology." International Review of Mission, 107(1): $5^{-22}$.

Klair, James A. (2020). "Reverse Mission: African Christians in Cambridge, London and Lagos.” PhD thesis, Divinity, University of Cambridge.

Knibbe, Kim Esther (2011). "Nigerian Missionaries in Europe: History Repeating Itself or a Meeting of Modernities?" Journal of Religion in Europe, 4(3):471-487.

Knippenberg, Hans (2006). "The Changing Relationship Between State and Church/ Religion in the Netherlands." GeoJournal, 67(4): 317-330.

Koning, Daniëlle (2011). "Importing God: The Mission of the Ghanaian Adventist Church and other Immigrant Churches in the Netherlands." Journal of Adventist Mission Studies, 7(2): 131-133.

Moreau, A. Scott (2012). Contextualization in World Missions: Mapping and Assessing Evangelical Models. Grand Rapids, MI: Kregel Academic. 
Moreau, A. Scott (2005). "Contextualization: From an Adapted Message to an Adapted Life.” In Michael Pocock, Gailyn van Rheenen, and Douglas McConnell, eds., The Changing Face of World Missions: Engaging Contemporary Issues and Trends. Grand Rapids: Baker Academic Press, 321-348.

Nel, Marious (2015). "An attempt to Define the Constitutive Elements of a Pentecostal Spirituality." die Skriflig/Luce Verbi, 49(1): 1-7.

Nyanni, Caleb O. (2021). Second-Generation African Pentecostals in the West: An Emerging Paradigm. Eugene, OR: Wipf and Stock Publishers.

Nyanni, Caleb O. (2018). The Spirits and Transition: The Second Generation and the Church of Pentecost - UK. PhD thesis, University of Birmingham.

Obinna, Elijah (2014). "African Christians in Scotland: Contesting the Rhetoric of Reverse Mission." In Afe Adogame, Elizabeth Olsen, Elijah Obinna, and Giselle Vincett, eds. Christianity in the Modern World: Changes and Controversies. London: Routledge, $77-94$.

Olofinjana, R. Israel O. (2020). "Reverse Mission: Towards an African British Theology." Transformation, 37(1): $5^{2-65}$.

Parekh, Bhikhu (2006). Rethinking Multiculturalism: Cultural Diversity and Political Theory. Basingstoke [England]; New York: Palgrave Macmillan.

Pears, Angie (2010). Doing Contextual Theology. Oxford: Routledge.

Poloma, Margaret (2003). Main Street Mystics: The Toronto Blessing and Reviving Pentecostalism. Lanham, MD: AltaMira Press.

Poloma, Margaret \& Ralph Hood, Jr. (2008). Blood and Fire: Godly Love in a Pentecostal Emerging Church. New York: NYU Press.

Reynolds, Tracey \& Zontini, Elisabetta (2016). "Transnational and Diasporic Youth Identities: Exploring Conceptual Themes and Future Research Agendas." Identities, 23(4): 379-391.

Schiller, Nina Glick and Evangelos Karagiannis (2009). “... The Land which the LORD Your God Giveth You': Two African Churches in Oststadt." In Afe Adogame, Roswith Gerloff, and Klaus Hock, eds., Christianity in Africa and the African Diaspora: The Appropriation of a Scattered Heritage. London: Continuum International Publishing Group, pp. 265-278.

Tano, Rodrigo D. (1981). Theology in the Philippine Setting: A Case Study in the Contextualization of Theology. New Day Publisher.

Ukah, Asonzeh F.-K. (2008). A New Paradigm of Pentecostal Power: A Study of the Redeemed Christian Church of God in Nigeria. Trenton, NJ and Asmara: Africa World Press.

Voas, David and Steve Bruce (2019). "Religion: Identity, Behaviour, and Belief over Two Decades." In Curtice, J., Clery, E., Perry, J., Phillips, M., and Rahim, N., eds. British Social Attitudes: The 36 th Report, London: The National Centre for Social Research: 17-44. Available at: https://www.bsa.natcen.ac.uk/media/39293/1_bsa36_religion .pdf. 
Währisch-Oblau, Claudia (2012). The Missionary Self-perception of Pentecostal/ Charismatic Church Leaders from the Global South in Europe: Bringing Back the Gospel. Leiden: Brill.

Wanner, Catherine (2004). "Missionaries of Faith and Culture: Evangelical Encounters in Ukraine." Slavic Review, 63 (4): 732-755.

Wariboko, Nimi (2014). Nigerian Pentecostalism. Rochester: University of Rochester Press.

\section{Resumen}

Las iglesias pentecostales lideradas por africanos, desde 1960, han incrementado en Europa/Reino Unido, y a menudo se ha identificado la evangelización de las poblaciones blancas locales como un anhelo misiológico clave. Este deseo aún no se ha cumplido, aunque por las estadísticas y la participación social, los pentecostales africanos se han hecho sentir y han retomado las conversaciones sobre religión a la esfera pública en Europa. Este artículo, basado en estudios de casos en Londres y Ámsterdam, se aparta de la erudición establecida sobre las "misiones inversas" al argumentar que los conflictos intergeneracionales, dentro de las iglesias pentecostales iniciadas por nigerianos en Europa, presentan un obstáculo significativo que obstaculiza sus objetivos misionales. Este estudio cualitativo se centra en los migrantes nigerianos de segunda generación y subsiguiente y sus percepciones de las actividades misiológicas y religiosas de la primera generación. Explora los conflictos intergeneracionales relacionados con el liderazgo, las creencias/prácticas indígenas, las normas culturales/ de género y enfoques misiológicos. Argumenta que abordar estos puntos de conflicto será una herramienta importante para el éxito misional de los pentecostales africanos en Europa.

\section{摘要}

自 20 世纪60年代以来, 以非洲主导的五旬宗教会在欧洲/英国蓬勃发展, 经常将向 白人居民传福音确定为一种主要的宣教愿望。这一愿望尚未实现, 尽管从人数和社 会参与度方面, 非洲五旬宗正在使他们的存在为人所知, 并将有关宗教的对话带到 欧洲的公共领域。本文基于伦敦和阿姆斯特丹的案例研究, 离开了关于 “反向宣 教” 的既定学术观点, 认为尼日利亚人发起的欧洲五旬宗教会内部的跨代冲突是阻 碍其传教目的的一大障碍。这一定性研究侧重于第二代和后代尼日利亚移民, 及其 对第一代移民宗教活动的看法, 探讨与领导有关的代际冲突; 本土信仰/习俗; 性 别/文化规范和宣教学方法。它认为, 解决这些冲突点将是非洲五旬宗派在欧洲取 得使命性成功的重要工具。 